\title{
Geology
}

\section{Uncovering framboidal pyrite biogenicity using nano-scale CNorg mapping --Manuscript Draft--}

Manuscript Number:

Full Title:

Short Title:

Article Type:

Keywords:

Corresponding Author:

\section{G36048R1}

Uncovering framboidal pyrite biogenicity using nano-scale CNorg mapping

Framboidal pyrite

Article

pyrite; framboids; sulfur isotopes; biomarker; biofilms

David Wacey

The University of Western Australia

Perth, Western Australia AUSTRALIA

Corresponding Author Secondary Information:

Corresponding Author's Institution:

The University of Western Australia

Corresponding Author's Secondary Institution:

First Author:

David Wacey

First Author Secondary Information:

Order of Authors:

David Wacey

Matt R Kilburn

Martin Saunders

John B Cliff

Charlie Kong

Alexander G Liu

Jack J Matthews

Martin D Brasier

Order of Authors Secondary Information:

\section{Manuscript Region of Origin:}

Abstract:

\section{CANADA}

Framboidal pyrite has been used as a paleo-redox proxy and a biomarker in ancient sediments, but the interpretation of pyrite framboids can be controversial, especially where later overgrowths have obscured primary textures. Here we show how nanoscale chemical mapping of organic carbon and nitrogen (CNorg) can detect relict framboids within Precambrian pyrite grains and determine their formation mechanism.

Pyrite grains associated with Ediacaran fossil lagerstätten from Newfoundland (c. 560 $\mathrm{Ma}$ ) hold significance for our understanding of taphonomy and redox history of the earliest macrofossil assemblages. They show distinct chemical zoning with respect to CNorg. Relict framboids are revealed as spheroidal zones within larger pyrite grains, whereby pure pyrite micro-crystals are enclosed by a mesh-like matrix of pyrite possessing elevated CNorg, replicating observations from framboids growing within modern biofilms. Subsequent pyrite overgrowths also incorporated CNorg from biofilms, with concentric CNorg zoning showing that the availability of CNorg progressively decreased during later pyrite growth. Multiple framboids are often cemented together by these overgrowths to form larger grains, with relict framboids only detectable in CNorg maps. In situ sulfur isotope data ( $\delta 34 \mathrm{~S}=$ c. $-24 \%$ to $-15 \%$ ) show that the source of sulfur for the pyrite was also biologically mediated, most likely via a sulfate-reducing microbial metabolism within the biofilms. Relict framboids have significantly smaller diameters than the pyrite grains that enclose them, suggesting that the use of framboid diameters to infer water column paleo-redox conditions should be 
approached with caution.

This work shows that pyrite framboids have formed within organic biofilms for at least $560 \mathrm{Ma}$, and provides a novel methodology that could readily be extended to search for such biomarkers in older rocks and potentially on other planets.

Response to Reviewers:

All responses are given in the attached cover letter 
Publisher: GSA

Journal: GEOL: Geology

DOI:10.1130/G36048.1

1 Uncovering framboidal pyrite biogenicity using nano-

2 scale $\mathrm{CN}_{\text {org }}$ mapping

3 David Wacey ${ }^{1,2}$, Matt R. Kilburn ${ }^{1,2}$, Martin Saunders ${ }^{2}$, John B. Cliff ${ }^{1,2}$, Charlie

4 Kong $^{3}$, Alexander G. Liu ${ }^{4}$, Jack J. Matthews ${ }^{5}$, and Martin D. Brasier ${ }^{5}$

$5{ }^{1}$ Australian Research Council Centre of Excellence for Core to Crust Fluid Systems,

6 The University of Western Australia, 35 Stirling Highway, Crawley, WA 6009,

$7 \quad$ Australia

$8 \quad{ }^{2}$ Centre for Microscopy Characterisation and Analysis, The University of Western

9 Australia, 35 Stirling Highway, Crawley, WA 6009, Australia

$10 \quad{ }^{3}$ Electron Microscopy Unit, University of New South Wales, Kingsford, NSW 2052,

11 Australia

$12{ }^{4}$ Department of Earth Sciences, University of Cambridge, Downing Street,

13 Cambridge, CB2 3EQ, UK

$14{ }^{5}$ Department of Earth Sciences, University of Oxford, South Parks Road, Oxford, OX1

$153 A N, U K$

16 ABSTRACT

Framboidal pyrite has been used as a paleo-redox proxy and a biomarker in

18 ancient sediments, but the interpretation of pyrite framboids can be controversial,

19 especially where later overgrowths have obscured primary textures. Here we show

20 how nano-scale chemical mapping of organic carbon and nitrogen $\left(\mathrm{CN}_{\text {org }}\right)$ can detect

21 relict framboids within Precambrian pyrite grains and determine their formation

22 mechanism.

Pyrite grains associated with Ediacaran fossil lagerstätten from Newfoundland

24 (c. $560 \mathrm{Ma}$ ) hold significance for our understanding of taphonomy and redox history 
Publisher: GSA

Journal: GEOL: Geology

DOI:10.1130/G36048.1

25 of the earliest macrofossil assemblages. They show distinct chemical zoning with

26 respect to $\mathrm{CN}_{\text {org. }}$. Relict framboids are revealed as spheroidal zones within larger

27 pyrite grains, whereby pure pyrite micro-crystals are enclosed by a mesh-like matrix

28 of pyrite possessing elevated $\mathrm{CN}_{\text {org }}$, replicating observations from framboids growing

29 within modern biofilms. Subsequent pyrite overgrowths also incorporated $\mathrm{CN}_{\text {org }}$ from

30 biofilms, with concentric $\mathrm{CN}_{\text {org }}$ zoning showing that the availability of $\mathrm{CN}_{\text {org }}$

31 progressively decreased during later pyrite growth. Multiple framboids are often

32 cemented together by these overgrowths to form larger grains, with relict framboids

33 only detectable in $\mathrm{CN}_{\text {org }}$ maps. In situ sulfur isotope data $\left(\delta^{34} \mathrm{~S}=\right.$ c. $-24 \%$ o to $-15 \%$ o $)$

34 show that the source of sulfur for the pyrite was also biologically mediated, most

35 likely via a sulfate-reducing microbial metabolism within the biofilms. Relict

36 framboids have significantly smaller diameters than the pyrite grains that enclose

37 them, suggesting that the use of framboid diameters to infer water column paleo-

38 redox conditions should be approached with caution.

39 This work shows that pyrite framboids have formed within organic biofilms

40 for at least $560 \mathrm{Ma}$, and provides a novel methodology that could readily be extended

41 to search for such biomarkers in older rocks and potentially on other planets.

INTRODUCTION

Framboidal pyrite is a common component of the geological record, often

being the most common pyrite texture in ancient sediments, but its formation mechanism has long been debated (Papunen, 1966; Ohfuji and Rickard, 2005; Ohfuji

et al., 2005; Rickard, 2012). Pyrite framboids are defined as microscopic spheroidal to 


\section{Publisher: GSA \\ Journal: GEOL: Geology \\ DOI: $10.1130 / \mathrm{G} 36048.1$}

50 Rickard, 2005), although they are most commonly 10-20 $\mu \mathrm{m}$ in diameter (Wilkin et

51 al., 1996; Wang et al., 2012). Pyrite framboids have been used as a proxy for local

52 redox conditions in paleo-environmental reconstructions, with their size distributions

53 used to discriminate between formation within euxinic water columns or in sediments

54 below oxygenated water columns (Wilkin et al., 1996; Wang et al., 2012). They have

55 also been suggested as potential biomarkers in very ancient sediments or on other

56 planets (Popa et al., 2004; MacLean et al., 2008). Hence, there is a pressing need for

57 robust ways to identify framboids, accurately measure their size distributions, and

58 determine their biogenicity throughout the geological record.

Early studies noted a frequent association of organic matter with pyrite

60 framboids, leading to the suggestion that their characteristic texture was directly

61 controlled by biology, with some studies speculating that framboids were pyritised

62 microfossils (e.g., Love, 1957). However, the discovery of framboids in high

63 temperature volcanic and hydrothermal settings (Love and Amstutz, 1969), plus the

64 experimental synthesis of pyrite framboids in the laboratory without the presence of

65 organic material (Sweeney and Kaplan, 1973), indicated that biology was not a pre-

66 requisite for framboid formation. Substantial debate followed about the extent to

67 which biology contributes to framboid formation (e.g., Ohfuji and Rickard, 2005;

68 Kohn et al., 1998). In modern low temperature sedimentary environments, much of

69 this debate was resolved by the work of Large et al. (2001) and MacLean et al.

70 (2008). These authors used high-spatial-resolution cryogenic-SEM (Large et al.,

71 2001), plus focused ion beam-SEM and X-ray spectroscopy (MacLean et al., 2008) to

72 demonstrate the presence of biofilms coating both the outer surface of complete pyrite

73 framboids and the surfaces of individual micro-crystals within a framboid. Partially

74 formed 'proto-framboids' were found to be embedded in particularly large quantities 
Publisher: GSA

Journal: GEOL: Geology

DOI:10.1130/G36048.1

75 of biofilm and possessed micro-crystals with anhedral crystal faces, suggesting that

76 biofilms provide an organic template (constrained growth space) for the growth and aggregation of pyrite micro-crystals (MacLean et al., 2008). Furthermore, the polysaccharide-dominated surfaces of biofilms have a strong affinity for $\mathrm{Fe}^{2+}$ ions, providing ideal nucleation sites for iron sulfides, and may also play a role in stabilizing the framboids during sediment compaction or disturbance (Large et al., 81 2001).

In ancient environments, however, where significant pyrite recrystallization may have taken place and framboid-containing rocks may have experienced both low temperature and high temperature conditions (cf. Scott et al., 2009), it is more difficult to securely identify pyrite framboids and to demonstrate a biological formation mechanism. Some ancient framboids still retain their characteristic morphology when viewed under reflected light or the SEM but many others, such as those studied here, may be 'hidden' within larger grains. Chemical etching may hint at hidden framboids (Rickard and Zweifel, 1975) and $\delta^{34} \mathrm{~S}$ data may indicate whether the sulfur incorporated into framboids has a biogenic source (Kohn et al., 1998), but

91 these data do not reveal whether framboid growth occurred within a biological matrix.

92 Furthermore, the small size of framboids means that conventional bulk isotopic and

93 elemental analyses lack the spatial resolution required to provide meaningful data.

94 Here we combine in situ secondary ion mass spectrometry (SIMS) and transmission

95 electron microscopy (TEM) to provide a new way to detect and measure relict

96 framboids within ancient pyrite grains, and evaluate the contribution of biology to

97 their nucleation and growth mechanisms. 
Publisher: GSA

Journal: GEOL: Geology

DOI:10.1130/G36048.1

99 Ion mapping was performed on portions of standard geological thin sections using a

100 CAMECA NanoSIMS 50, with instrument parameters optimized as described in

101 Wacey et al. (2011). TEM wafers were extracted from geological thin sections using a

102 FEI xT Nova NanoLab 200 focused ion beam-scanning electron microscope, and

103 TEM data were obtained using a FEI Titan G2 80-200 TEM/STEM with ChemiSTEM

104 Technology, plus a JEOL $2100 \mathrm{LaB}_{6}$ TEM. Sulfur isotope data were obtained using a

105 CAMECA NanoSIMS 50 and a CAMECA IMS 1280, following protocols described in

106 McLoughlin et al. (2012) and Farquhar et al. (2013) respectively. For detailed

107 methods see GSA Data Repository item 2014xxx.

108 RESULTS AND DISCUSSION

109 Pyrite Chemistry and Nanotexture

110 Turbiditic siltstones of the $\sim 560$ Ma Fermeuse Formation at Back Cove,

111 Bonavista Peninsula, Newfoundland, contain clusters and laminae of small $(<50 \mu \mathrm{m})$

112 pyrite grains (Fig. DR1). Pyrite morphology ranges from rounded, through to

113 subhedral and euhedral cubes. Secondary electron (SE) images and NanoSIMS sulfur

$114\left({ }^{34} \mathrm{~S}^{-}\right)$ion maps show no indication of framboidal morphologies; indeed they indicate a

115 rather homogenous textural and chemical composition for all pyrite grains (Figs. 1,

$1162 \mathrm{c})$, with no significant differences between small rounded grains and larger euhedral

117 grains (compare ${ }^{34} \mathrm{~S}^{-}$images of small rounded grain at top of Figure 1 with large grain

118 in Fig. 2). In contrast, carbon $\left({ }^{12} \mathrm{C}^{-}\right)$and nitrogen $\left({ }^{26} \mathrm{CN}^{-}\right)$NanoSIMS ion maps reveal

119 distinct nano-scale chemical zoning within and between these grains. Many pyrite

120 grains possess an inner spheroidal zone (ISZ; Figure 1, dashed circle in enlarged

$121{ }^{26} \mathrm{CN}^{-}$map) comprising numerous micro-crystals of pure pyrite (Fig. 1, black cuboids

122 in enlarged ${ }^{26} \mathrm{CN}^{-}$map) set within a mesh-like matrix of C-and N-rich pyrite (Fig. 1,

123 pink areas within dashed circle in ${ }^{26} \mathrm{CN}^{-}$map). The ISZ is usually surrounded by an 
Publisher: GSA

Journal: GEOL: Geology

DOI:10.1130/G36048.1

124 outer zone (OZ) of C- and N-rich pyrite (Fig. 1, outer blue and pink zones). Co-

125 occurrence of $\mathrm{C}$ and $\mathrm{N}$, combined with the absence of ions such as $\mathrm{Ca}$ or $\mathrm{O}$, indicates

126 that the $\mathrm{C}$ and $\mathrm{N}$ signals come from organic material preserved within the pyrite

127 grains (from now on referred to as $\mathrm{CN}_{\text {org }}$ ).

128 TEM images of ultrathin $(\mathrm{c} .100 \mathrm{~nm})$ cross sections through well-preserved

129 grains demonstrate the nano-texture of the ISZ and the OZ, and also show that the

130 grains have a distinct thin $(<500 \mathrm{~nm})$ outer rim (Fig. 2d-e). In the ISZ, pyrite micro-

131 crystals are close packed, as expected for framboidal pyrite (cf. Ohfuji and Rickard,

132 2005), and each of these pyrite micro-crystals has a thin (c.50-100 nm) nano-porous

133 rim (Fig. 2d-e, arrows). The OZ also has a nano-porous texture and these pores tend to

134 be slightly larger than those in the ISZ (Fig. 2c). The nano-porous rims of the ISZ

135 together with the nano-porous $\mathrm{OZ}$ correspond precisely to the areas of $\mathrm{CN}_{\text {org }}$

136 enrichment seen in NanoSIMS ion maps. Unfortunately, the relatively poor detection

137 limits for $\mathrm{N}$, together with the extreme thinness of the TEM sample, preclude accurate

138 mapping of $\mathrm{CN}_{\text {org }}$ in the TEM. Only relatively large clumps of $\mathrm{CN}_{\text {org }}$ at some crystal

139 boundaries can be visualized in the TEM (Fig. DR2). We suggest that the nano-pores

140 house the remaining $\mathrm{CN}_{\text {org }}$ seen in NanoSIMS maps, but it is also possible that $\mathrm{CN}_{\text {org }}$

141 is held within the pyrite crystal lattice itself in these areas. Arsenic and nickel occur in

142 trace amounts restricted to the nano-porous rims of the ISZ (and to a lesser amount in

143 the $\mathrm{OZ}$ ), correlating with the $\mathrm{CN}_{\text {org }}$ enrichment seen in the NanoSIMS maps (Fig.

144 DR2). At the boundary between the ISZ and the OZ, the ISZ micro-crystals are

145 sharply terminated against the OZ (Fig. 2d, white line) and are not equimorphic with

146 micro-crystals toward the center of the ISZ. This suggests either recrystallization of

147 outer portions of the ISZ to form the OZ or a fairly rapid change in local chemistry,

148 such as reduction of free iron concentration, that changed pyrite growth morphology. 
Publisher: GSA

Journal: GEOL: Geology

DOI:10.1130/G36048.1

149 The thin outer rim records minor late-stage oxidation of pyrite to iron oxide (Fig.

150 DR3).

151 Some single pyrite grains possess several ISZ separated and surrounded by OZ

152 pyrite (Fig. 2a-b; Fig. DR4). In these cases, the grains often exhibit a rather euhedral

153 shape that disguises their original formation mechanism (Fig. 2). In other examples,

154 the $\mathrm{OZ}$ is chemically heterogenous in $\mathrm{CN}_{\text {org }}$, with clear concentric zoning marked by

155 outward-decreasing $\mathrm{CN}_{\text {org }}$ contents (Fig. DR5). Occasionally the $\mathrm{CN}_{\text {org }}$ chemical

156 microstructure of the ISZ is completely lost and only a spheroid of pure pyrite is seen

157 (Fig. DR6).

158 We interpret the ISZ in these grains as relict primary pyrite framboids and the

159 OZ as secondary pyrite. For those pyrite grains that possess several ISZ, these are

160 interpreted as multiple, closely spaced relict primary framboids that were cemented

161 together by secondary pyrite overgrowths. The distribution of $\mathrm{CN}_{\text {org }}$ in most ISZ

162 closely resembles the pattern of organic enrichment seen in modern framboidal pyrite

163 that nucleated and grew within biofilms (Large et al., 2001). The nano-texture of the

164 ISZ is also near identical to that seen in modern biologically-mediated framboids,

165 where every pyrite micro-crystal in the framboid is enclosed by a thin biofilm

166 (compare Figure 2d-e with fig. 2c of MacLean et al., 2008). Hence, we conclude that

167 our 560 Ma framboids likewise nucleated and grew within biofilms, or within some

168 other organic material such as extra-cellular polymeric substances (EPS). Wispy

169 carbonaceous laminae observed in thin sections close to the framboid-bearing layer

170 (Fig. DR1a) likely represent the remains of biofilms. Biofilms provide a number of

171 favorable conditions for framboid formation: 1) the organic framework provides a

172 pre-existing confined growth space that can control crystal size and morphology

173 (MacLean et al., 2008); 2) biofilms replicate conditions of high Fe and S 
Publisher: GSA

Journal: GEOL: Geology

DOI:10.1130/G36048.1

174 supersaturation (required for successful experimental abiotic precipitation of pyrite

175 framboids; Ohfuji and Rickard, 2005) so that nucleation rate is significantly greater

176 than crystal growth rate; 3) biofilms contain large amounts of polysaccharides that

177 have a high $\mathrm{Fe}^{2+}$ binding capacity, enhancing crystal nucleation (Flemming, 1995;

178 likewise, $\mathrm{Ni}$ and As could also be preferentially bound by biofilms, consistent with

179 their enrichment in $\mathrm{CN}_{\text {org }}$ zones); 4) cell walls within biofilms provide further

180 preferred nucleation sites for metal sulfides (Ferris et al., 1987); and 5) metal-

181 reducing and sulfate-reducing bacteria in biofilms can provide a local source of

182 reactive iron and sulfide (Rickard, 2012). In modern framboids, a layer of biofilm also

183 tends to enclose the entire framboid (Large et al., 2001; MacLean et al., 2008). While

184 this could equate to the $\mathrm{OZ}$ observed in our pyrite grains, our OZ are much thicker

185 than modern biofilm coatings. This, together with our nano-textural observations

186 above, suggests the OZ is instead a zone of secondary overgrowth and/or

187 recrystallisation.

188 Insights from Sulfur Isotope Geochemistry

189 Sulfur isotope data (Table DR1; Fig. 3) were obtained in situ from polished

190 geological thin sections using Cameca NanoSIMS 50 and Cameca IMS 1280 ion

191 probes. Pyrite grains show a uniformly light $\delta^{34} \mathrm{~S}$ signal (-15.2 \%o to $-24.3 \%$; mean

$192=-21.5 \% ; \mathrm{n}=33)$. There is no significant difference in data obtained using

193 NanoSIMS (mean $=-21.7 \%$ ) and IMS $1280($ mean $=-21.4 \%)$.

This spatially resolved $\delta^{34} \mathrm{~S}$ data informs on the source of the sulfur for the

195 pyrite. Taking $\delta^{34} \mathrm{~S}=+25 \%$ as a mean estimate for the isotopic composition of

196 seawater sulfate at this time (Fike et al., 2006), then the pyrite grains show maximum

197 fractionations from Ediacaran seawater sulfate $\left(\Delta \delta^{34} S\right)$ of almost $50 \%\left(\Delta \delta^{34} S=40.2-\right.$

$19849.3 \%$ ). This clearly shows biological processing of sulfur prior to incorporation into 
Publisher: GSA

Journal: GEOL: Geology

DOI:10.1130/G36048.1

199 the pyrite. Such large $\Delta \delta^{34} S$ fractionations may occur in two ways: 1) during

200 microbial sulfate reduction (MSR) under conditions of limited electron donor supply

201 and/or poor reactivity of organic material (Leavitt et al., 2013); and 2) during

202 oxidative sulfur cycling where fractionations associated with MSR are supplemented

203 by those occurring during disproportionation of oxidized sulfide (Canfield and

204 Thamdrup, 1994). We favor the former mechanism here due to the inferred deep-sea

205 setting (Hofmann et al., 2008), leading to low $\mathrm{C}_{\text {org }}$ delivery and relatively low total

206 organic carbon (TOC) contents of these sediments (mostly $<0.1 \mathrm{wt} \%$; Canfield et al.,

207 2007). Although microbial biomorphs have not yet been observed in the pyrite grains,

208 it is likely that sulfate-reducing bacteria were part of the living biofilm in which the

209 framboids nucleated and grew, producing a localized source of ${ }^{34} \mathrm{~S}$-depleted $\mathrm{H}_{2} \mathrm{~S}$ for

210 incorporation into the pyrite micro-crystals.

$211 \delta^{34} \mathrm{~S}$ does not change significantly with distance from the center of a pyrite

212 grain (Fig. 3). This supports our earlier hypothesis that pyrite overgrowths could have

213 resulted from recrystallization of primary framboidal zones (hence inheriting their

214 isotopic signal). This mechanism is also consistent with the homogenous enrichment

215 of $\mathrm{CN}_{\text {org }}$ in the overgrowths of many grains; here, $\mathrm{CN}_{\text {org }}$ that was present in biofilms

216 coating framboid micro-crystals could be redistributed and incorporated into nano-

217 pores or the crystal lattice of pyrite as it recrystallized. For those grains with

218 concentrically zoned and outward-diminishing $\mathrm{CN}_{\text {org }}$ contents (e.g., Fig. DR5), we

219 infer that recrystallization was followed by continued early diagenetic pyrite growth

220 in pore-waters that were $\mathrm{CN}_{\text {org }}$ poor but were still open to a supply of iron and

221 seawater sulfate (hence, no Rayleigh-type ${ }^{34} \mathrm{~S}$ enrichment in the $\delta^{34} \mathrm{~S}$ data).

222 Implications for the use of Framboid Diameters as a Paleo-redox Proxy 
Publisher: GSA

Journal: GEOL: Geology

DOI:10.1130/G36048.1

Framboid diameters have been used to determine whether pyrite precipitation

224 took place within a euxinic water column or within sediments below an oxic or

225 dysoxic water column (e.g., Wilkin et al., 1996; Wang et al., 2012). In modern

226 environments, framboids precipitated within a euxinic water column over a short

227 timespan tend to be $<10 \mu \mathrm{m}$ in diameter, whereas those precipitated in sediment

228 porewaters have larger and more variable diameters (Wilkin et al., 1996). This

229 protocol has been extended into the geological record and used to infer the oxidation

230 state of some ancient water columns (Wang et al., 2012). However, when we compare

231 the diameters of the relict framboids (defined as the ISZ in the NanoSIMS CN $\mathrm{org}_{\text {}}$

232 maps) with the total diameter of the enclosing grains, we find that the relict framboids

233 make up only $15 \%$ to $71 \%$ of total grain diameter $(n=28)$. Moreover, several

234 enclosing grains retain a spheroidal, pseudo-framboidal shape despite clearly not

235 being primary framboids. These data suggest simple transects using light or electron

236 microscopy are insufficient to determine the portion of a framboid that is primary in

237 nature and hence extreme caution should be exercised if attempting to use framboid

238 diameters as paleo-redox proxies.

\section{CONCLUSION}

Pyrite grains from 560 Ma sediments exhibit distinctive distributions of $\mathrm{CN}_{\text {org }}$

241 that highlight zones of primary framboid growth and subsequent pyrite overgrowths.

242 The pattern of $\mathrm{CN}_{\text {org }}$ enrichment correlates with pyrite nano-textures showing that

243 organic material is retained at grain boundaries between pyrite micro-crystals and in

244 thin nano-porous rims coating each micro-crystal. Organic material is also found

245 preserved in pyrite overgrowth zones but frequently decreases outwards with

246 progressive overgrowth. The $\mathrm{CN}_{\text {org }}$ distribution permits accurate measurements of

247 relict framboid versus overgrowth diameters, which is essential if framboids are to be 
Publisher: GSA

Journal: GEOL: Geology

DOI:10.1130/G36048.1

248 used as paleo-redox proxies. Our data show that 560 Ma framboids nucleated and

249 grew within organic biofilms, extending geological evidence for this growth

250 mechanism back into the Precambrian. These biofilms also contained sulfate-reducing

251 bacteria, and perhaps also metal reducing bacteria, that provided a local source of

252 reduced $\mathrm{S}$ and $\mathrm{Fe}$ for the pyrite. Our work provides a straightforward protocol for

253 finding hidden framboids in larger euhedral crystals, and for determining the

254 biogenicity of ancient framboids, enhancing their potential as biomarkers on the early

255 Earth and other planets.

256 ACKNOWLEDGMENTS

We acknowledge the Australian Microscopy \& Microanalysis Research

Facility at The University of Western Australia and The University of New South Wales. These facilities are funded by the Universities, State and Commonwealth Governments. DW is funded by the Australian Research Council, via a grant to the Centre of Excellence for Core to Crust Fluid Systems.

\section{REFERENCES CITED}

Canfield, D.E., and Thamdrup, B., 1994, The production of ${ }^{34}$ S-depleted sulphide during bacterial disproportionation of elemental sulfur: Science, v. 266, p. 19731975, doi:10.1126/science.11540246.

Canfield, D.E., Poulton, S.W., and Narbonne, G.M., 2007, Late-Neoproterozoic deepocean oxygenation and the rise of animal life: Science, v. 315, p. 92-95, doi:10.1126/science.1135013.

269 Farquhar, J., Cliff, J., Zerkle, A.L., Kamyshny, A., Poulton, S.W., Claire, M., Adams, 270 D., and Harms, B., 2013, Pathways for Neoarchean pyrite formation constrained by mass-independent sulfur isotopes: Proceedings of the National Academy of 


\section{Publisher: GSA \\ Journal: GEOL: Geology \\ DOI: $10.1130 / \mathrm{G} 36048.1$}

273 Ferris, F.G., Fyfe, W.S., and Beveridge, T.J., 1987, Bacteria as nucleation sites for authigenic minerals in a metal-contaminated lake sediment: Chemical Geology, v. 63, p. 225-232, doi:10.1016/0009-2541(87)90165-3.

Fike, D., Grotzinger, J., Pratt, L., and Summons, R., 2006, Oxidation of the Ediacaran ocean: Nature, v. 444, p. 744-747, doi:10.1038/nature05345.

Flemming, H.-C., 1995, Sorption sites in biofilms: Water Science and Technology, v. 32, p. 27-33, doi:10.1016/0273-1223(96)00004-2.

Hofmann, H.J., O’Brien, S.J., and King, A.F., 2008, Ediacaran biota on Bonavista Peninsula, Nefoundland, Canada: Journal of Paleontology, v. 82, p. 1-36, doi:10.1666/06-087.1.

Kohn, M.J., Riciputi, L.R., Stakes, D., and Orange, D.L., 1998, Sulfur isotope variability in biogenic pyrite: Reflections of heterogenous bacterial colonization?: The American Mineralogist, v. 83, p. 1454-1468.

Large, D.J., Fortey, N.J., Milodowski, A.E., Christy, A.G., and Dodd, J., 2001, Petrographic observations of iron, copper, and zinc sulphides in freshwater canal sediment: Journal of Sedimentary Research, v. 71, p. 61-69, doi:10.1306/052600710061.

Leavitt, W.D., Halevy, I., Bradley, A.S., and Johnston, D.T., 2013, Influence of sulfate reduction rates on the Phanerozoic sulfur isotope record: Proceedings of the National Academy of Sciences of the United States of America, v. 110, p. 11244-11249, doi:10.1073/pnas.1218874110.

Love, L.G., 1957, Micro-organisms and the presence of syngenetic pyrite: Quarterly Journal of the Geological Society of London, v. 113, p. 429-440, doi:10.1144/GSL.JGS.1957.113.01-04.18. 
Publisher: GSA

Journal: GEOL: Geology

DOI:10.1130/G36048.1

Jahrbuch für Mineralogie, Monatshefte, v. 3, p. 97-108.

299 MacLean, L.C.W., Tyliszczak, T., Gilbert, P.U.P.A., Zhou, D., Pray, T.J., Onstott, T.C., and Southam, G., 2008, A high-resolution chemical and structural study of framboidal pyrite formed within a low-temperature bacterial biofilm: Geobiology, v. 6, p. 471-480, doi:10.1111/j.1472-4669.2008.00174.x.

McLoughlin, N., Grosch, E.G., Kilburn, M.R, and Wacey, D., 2012, Sulfur isotope evidence for a Paleoarchean subseafloor biosphere, Barberton, South Africa: Geology, v. 40, p. 1031-1034.

Ohfuji, H., and Rickard, D., 2005, Experimental synthesis of framboids - a review: Earth-Science Reviews, v. 71, p. 147-170, doi:10.1016/j.earscirev.2005.02.001.

Ohfuji, H., Boyle, A.P., Prior, D.J., and Rickard, D., 2005, Structure of framboidal pyrite: an electron backscatter diffraction study: American Mineralogist, v. 90, p.

Papunen, H., 1966, Framboidal texture of the pyritic layer found in a peat bog in S.E. Finland: Comptes Rendus de la Société Géologique de Finlande, v. 38, p. 117125.

Popa, R., Badescu, A., and Kinkle, B.K., 2004, Pyrite framboids as biomarkers for iron-sulfur systems: Geomicrobiology Journal, v. 21, p. 193-206, doi:10.1080/01490450490275497.

Rickard, D.T., and Zweifel, H., 1975, Genesis of Precambrian sulfide ores, Skellefte district, Sweden: Economic Geology, v. 70, p. 255-274.

Rickard, D., 2012, Sulfidic Sediments and Sedimentary Rocks: Amsterdam, Elsevier, 816 p.

321 Scott, R.J., Meffre, S., Woodhead, J., Gilbert, S.E., Berry, R.F., and Emsbo, P., 2009, 322 Development of framboidal pyrite during diagenesis, low-grade regional 
Publisher: GSA

Journal: GEOL: Geology

DOI:10.1130/G36048.1

metamorphism, and hydrothermal alteration: Economic Geology and the Bulletin of the Society of Economic Geologists, v. 104, p. 1143-1168, doi:10.2113/gsecongeo.104.8.1143.

Sweeney, R.E., and Kaplan, I.R., 1973, Pyrite framboid formation: Laboratory synthesis and marine sediments: Economic Geology, v. 68, p. 618-634.

Wacey D., Kilburn, M.R., Saunders, M., Cliff, J., and Brasier, M.D., 2011, Microfossils of sulphur-metabolizing cells in 3.4 billion-year-old rocks of Western Australia: Nature Geoscience, v. 4, p. 698-702.

331 Wang, L., Shi, X., and Jiang, G., 2012, Pyrite morphology and redox fluctuations recorded in the Ediacaran Doushantuo Formation: Palaeogeography, Palaeoclimatology, Palaeoecology, v. 333-334, p. 218-227, doi:10.1016/j.palaeo.2012.03.033.

335 Wilkin, R.T., Barnes, H.L., and Brantley, S.L., 1996, The size distribution of framboidal pyrite in modern sediments: An indicator of redox conditions: Geochimica et Cosmochimica Acta, v. 60, p. 3897-3912, doi:10.1016/0016-

339 Figure 1. Secondary electron image (SE) and NanoSIMS ion maps of sulfur $\left({ }^{34} \mathrm{~S}^{-}\right)$, 340 nitrogen $\left({ }^{26} \mathrm{CN}^{-}\right)$and carbon $\left({ }^{12} \mathrm{C}^{-}\right)$showing the internal $\mathrm{CN}_{\text {org }}$ zoning of 560 Ma pyrite 341 framboids. Two main zones are present: an inner spheroidal zone (ISZ) comprising 342 numerous micro-crystals of pure pyrite set within a matrix of $\mathrm{CN}_{\text {org }}$-rich pyrite; and an 343 outer, more homogenous zone (OZ) of $\mathrm{CN}_{\text {org }}$-rich pyrite that overgrows the

344 framboids, causing some to be cemented together. Note that neither the sulfur map 345 nor SE image reveal the true structure of the pyrite. NanoSIMS sulfur isotope analysis 346 craters are visible as darker squares in the $\mathrm{SE}$ and ${ }^{34} \mathrm{~S}^{-}$images. The black matrix in the 347 SE image is quartz and clay. 
Publisher: GSA

Journal: GEOL: Geology

DOI: $10.1130 / \mathrm{G} 36048.1$

348 Figure 2. a-c) Modification of framboidal pyrite structure by euhedral overgrowths.

349 Overgrowths on the central row of framboids have subhedral to euhedral crystal form

350 and disguise the true nature of the framboids. White line in (b) shows approximate

351 location of TEM sample analyzed in (d-e). d) Dark-field scanning TEM image of an

352 ultrathin slice $(\mathrm{c} .100 \mathrm{~nm})$ through a pyrite framboid, highlighting the differences in

353 nano-texture between the inner spheroidal zone (ISZ), nano-porous overgrowth zone

354 (OZ) and outer rim. e) Higher magnification view of the ISZ showing clear nano-

355 porous rims to each pyrite microcrystal (arrows, plus tangential section through the

356 edge of a micro-crystal ' 1 ').

357 Figure 3. Example of sulfur isotope data $\left(\delta^{34} \mathrm{~S} \%\right.$ ) obtained in situ from framboidal

358 pyrite in the c. $560 \mathrm{Ma}$ Fermeuse Formation. These rather homogenous and light $\delta^{34} \mathrm{~S}$

359 values suggest the source of sulfur for the framboidal pyrite was microbial sulfate

360 reduction under conditions of electron donor limitation.

$361{ }^{1}$ GSA Data Repository item 2014xxx, xxxxxxxx, is available online at

362 www.geosociety.org/pubs/ft2014.htm, or on request from editing@geosociety.org or

363 Documents Secretary, GSA, P.O. Box 9140, Boulder, CO 80301, USA. 


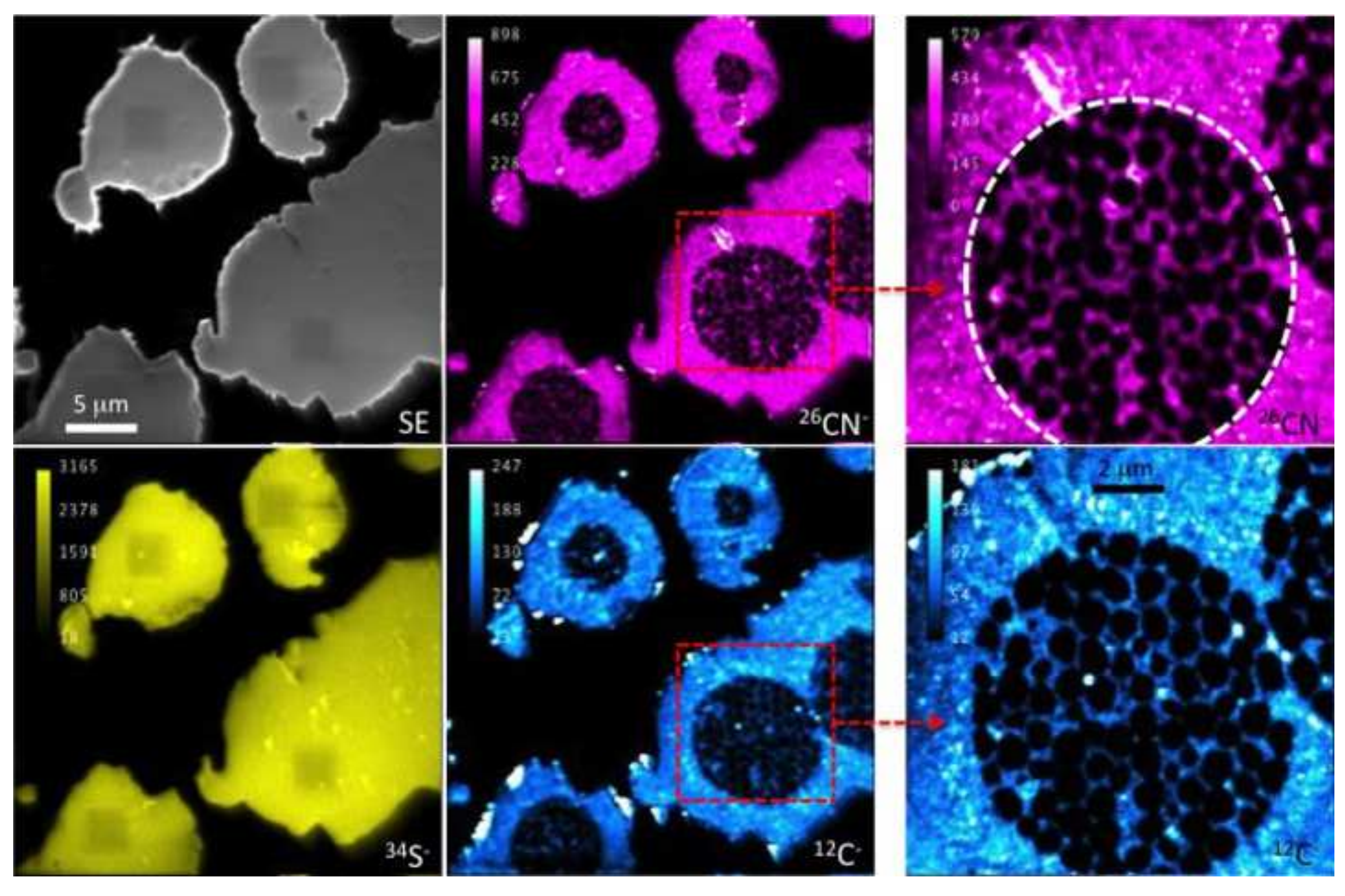


Click here to download high resolution image

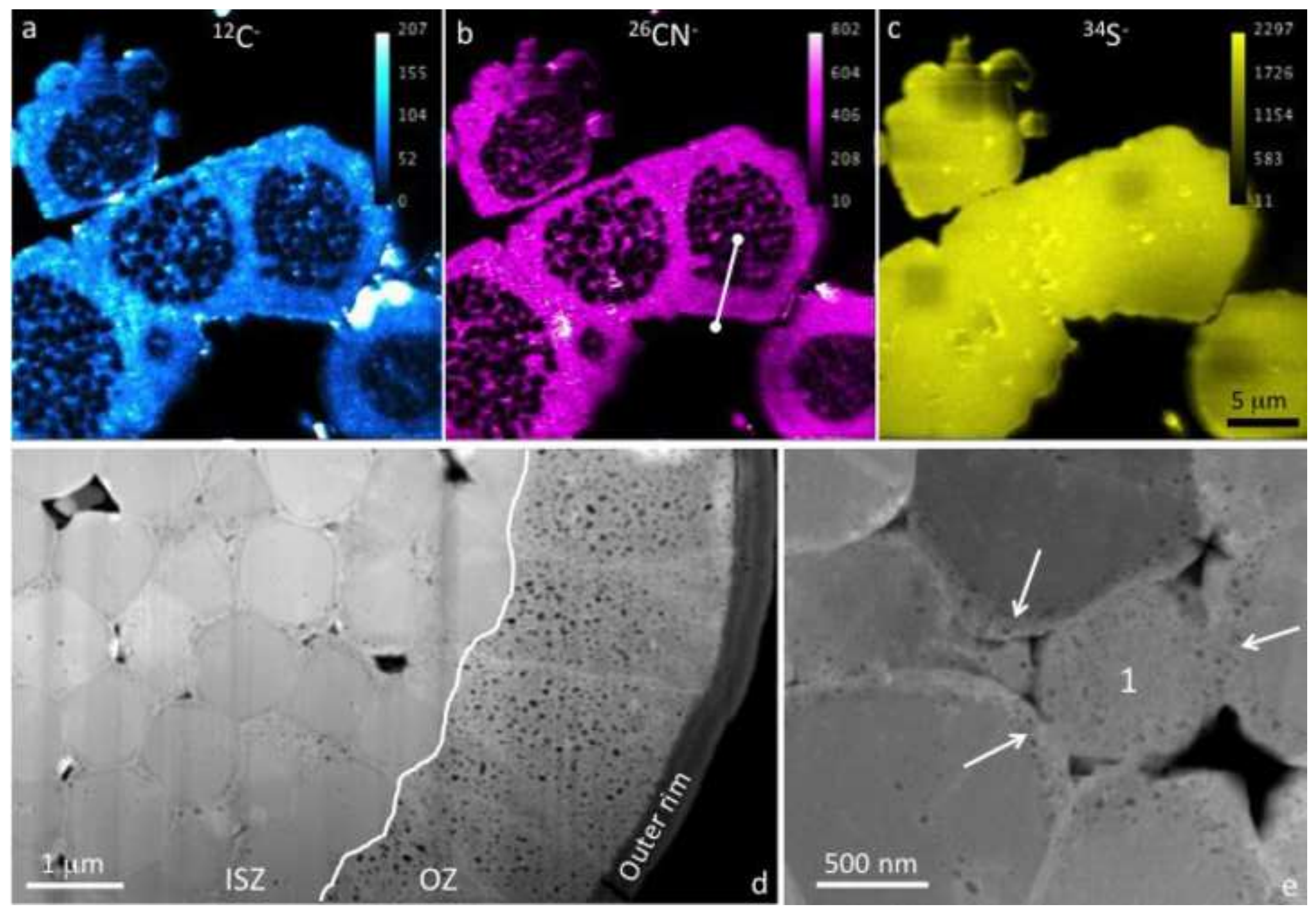


Sample WM1 $\left(\delta^{34} \mathrm{~S} \%\right.$ )

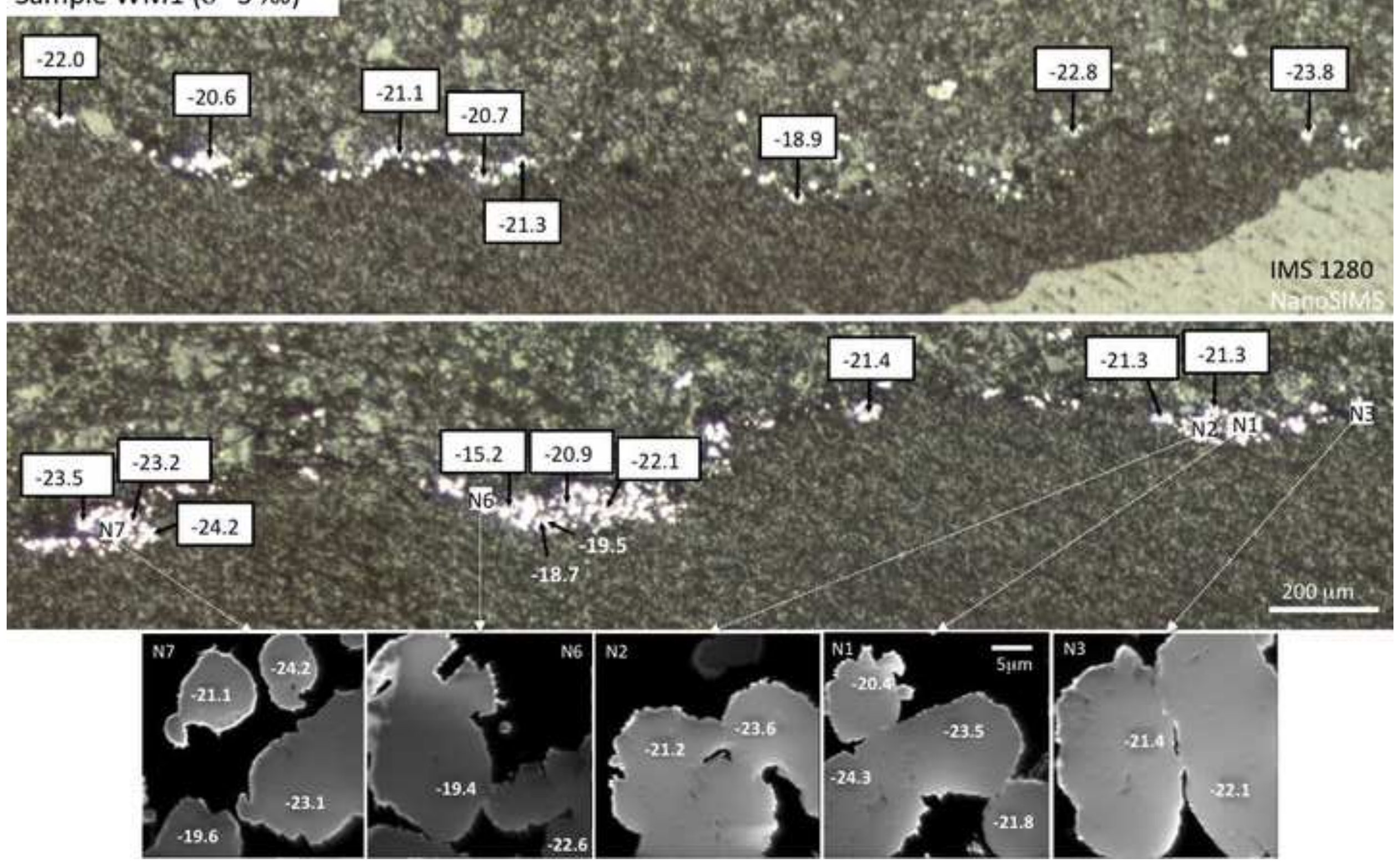




\section{GSA Data Repository Item 2014-XXXX}
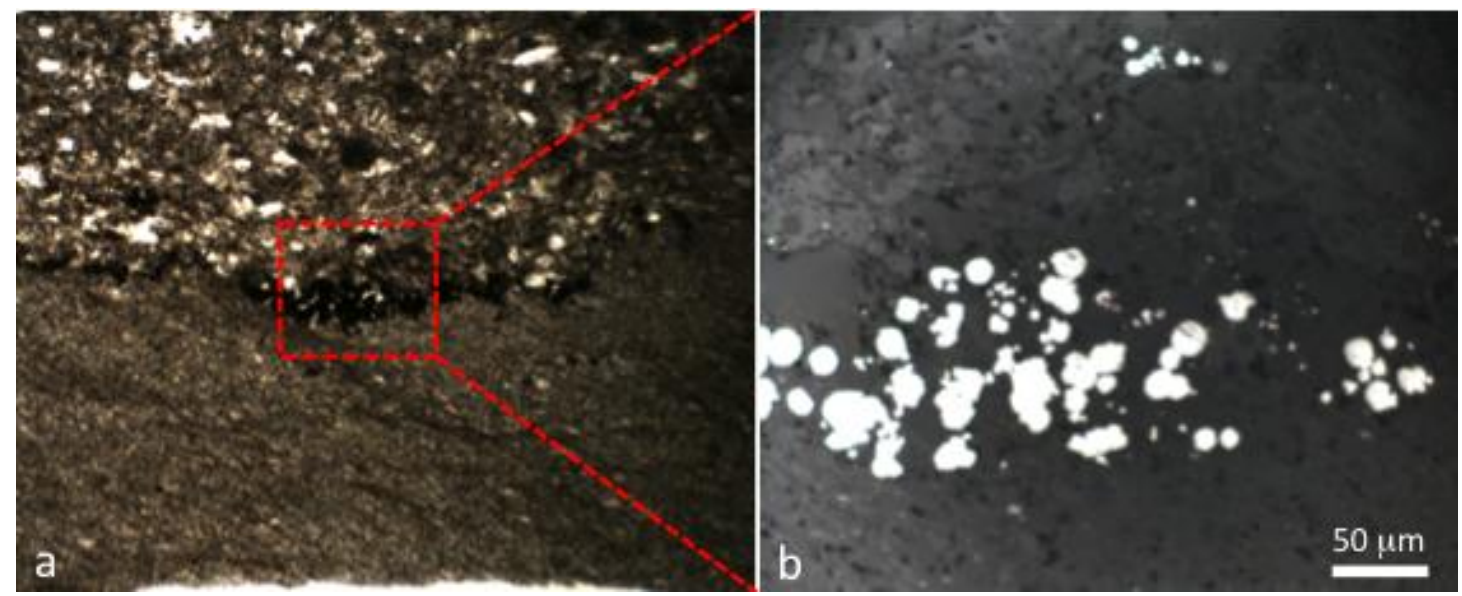

Figure DR1. Occurrence of putative framboidal pyrite from the late Ediacaran of the

Catalina Dome, Bonavista Peninsula, Newfoundland (sample WM1, c. 560 Ma

Fermeuse Formation). a) Thin section in plane-polarised light showing how

framboidal pyrite typically occurs on bedding plane surfaces between a lower

mudstone and an upper coarser siltstone or reworked volcanic ash. Impressions of

Ediacaran organisms such as Charniodiscus sp. and Bradgatia sp. are found on this same bedding surface. Note also the wispy carbonaceous laminae that probably represent the remnants of biofilms. b) Higher magnification reflected light image, revealing that the pyrite occurs as both single sub-spherical grains and clusters of cemented and overgrown grains. 


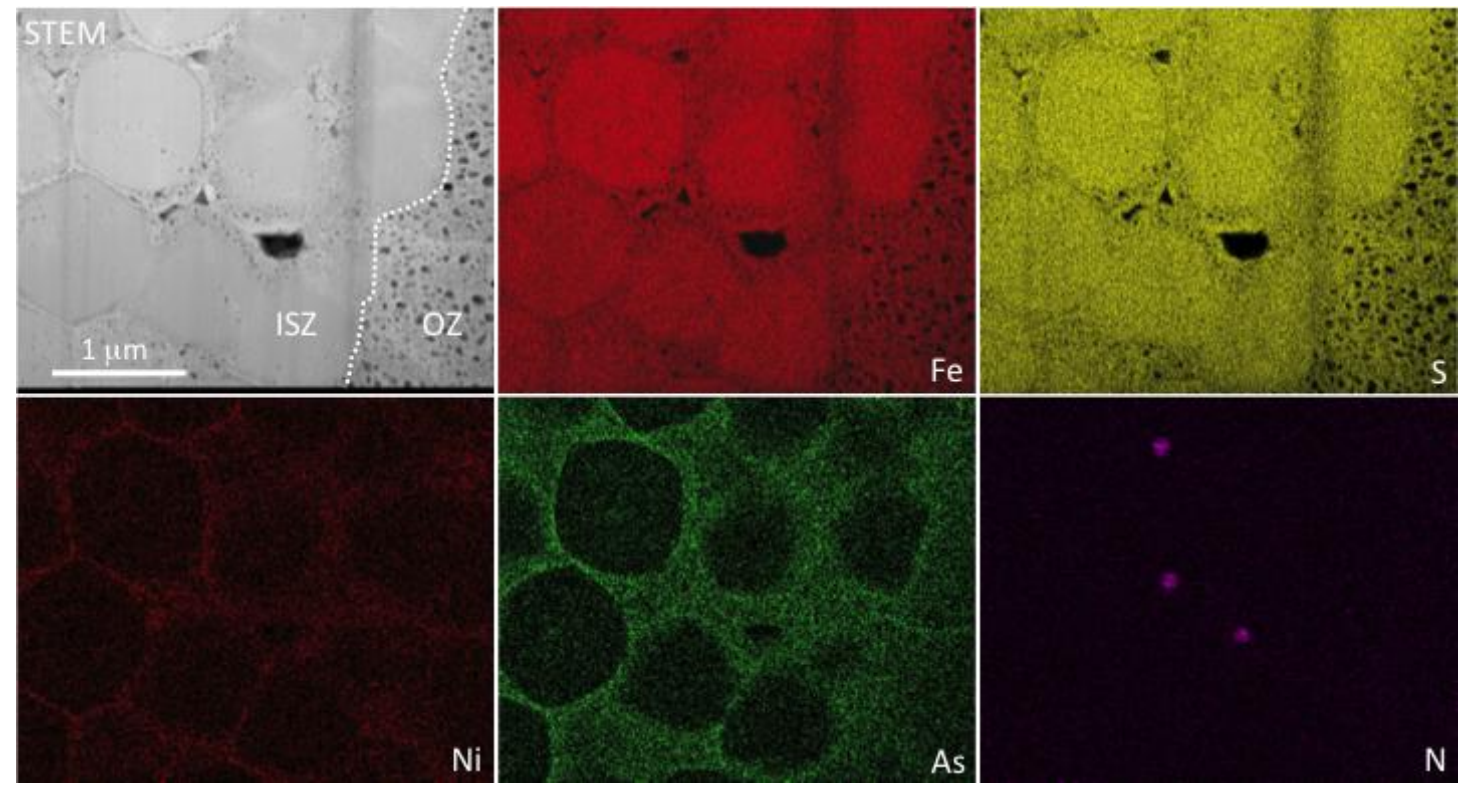

Figure DR2. Dark-field scanning transmission electron microscope (STEM) image, plus ChemiSTEM maps of part of a pyrite framboid (brighter colours indicate higher concentrations of each element). Arsenic and nickel are enriched in the nano-porous rims of the pyrite microcrystals in the ISZ, and also to a lesser extent in the OZ. Nitrogen is seen at some triple junctions in the ISZ, reinforcing our NanoSIMS data. However, the overall pattern of $\mathrm{N}$ enrichment seen in NanoSIMS maps is not visible here. This is due to the extreme thinness of the TEM sample and the poorer detection limits for $\mathrm{N}$ in the TEM. 


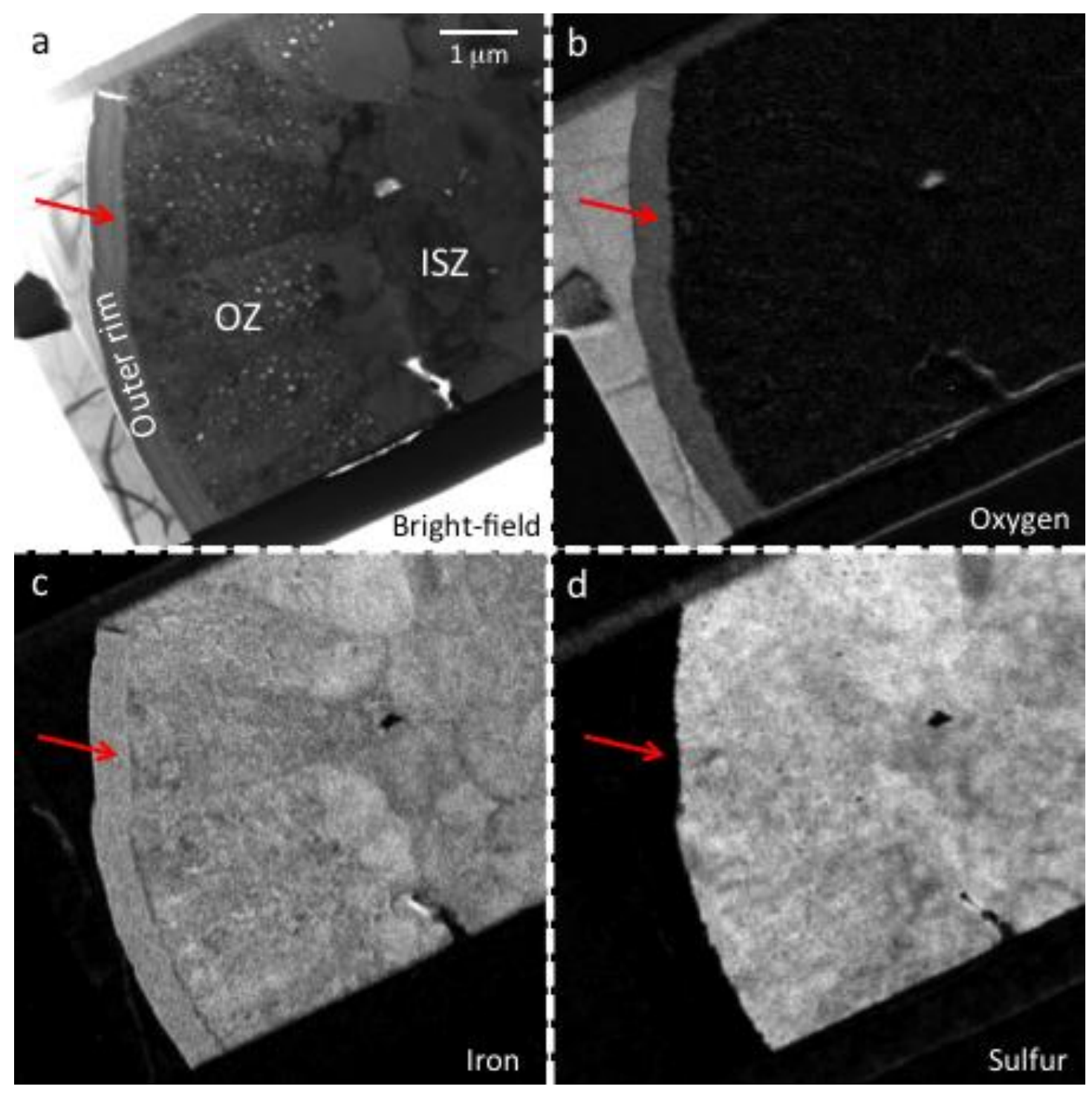

Figure DR3. Bright-field TEM image and energy-filtered (EFTEM) elemental maps from the outer part of a pyrite grain. While the ISZ and OZ are clearly composed of pyrite, the outer rim contains no sulfur and has been oxidised to iron oxide (arrow).

The mineral to the left of the iron oxide rim is silica, hence the high oxygen signal. 


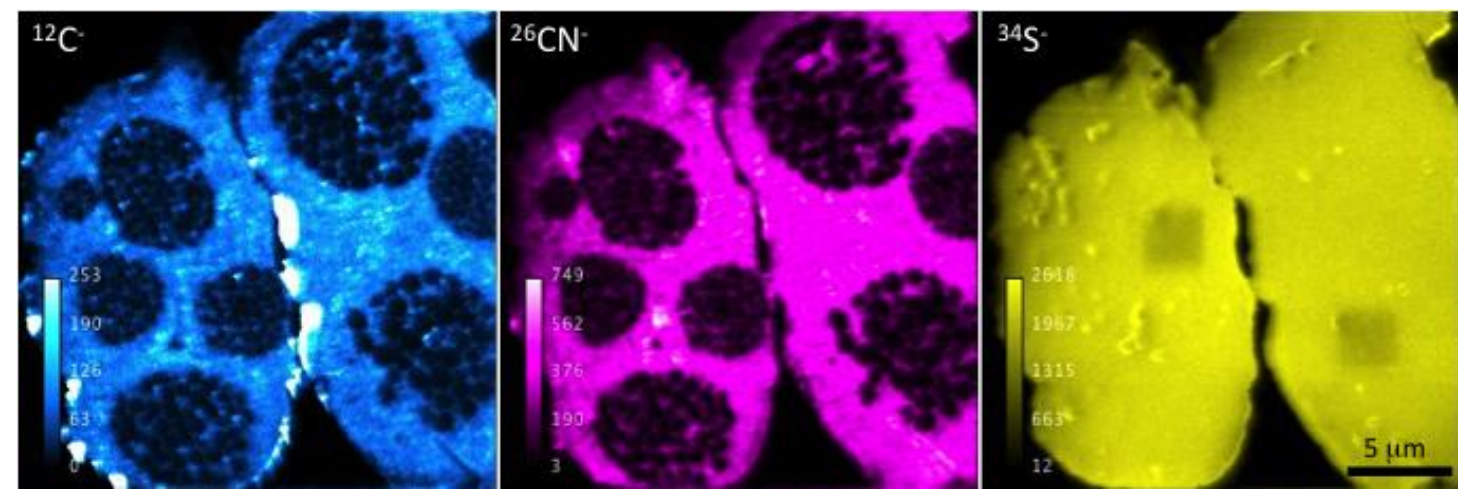

Figure DR4. NanoSIMS ion maps of carbon $\left({ }^{12} \mathrm{C}^{-}\right)$, nitrogen $\left({ }^{26} \mathrm{CN}^{-}\right)$and sulfur $\left({ }^{34} \mathrm{~S}^{-}\right)$ showing organic-rich pyrite overgrowth and cementation of numerous individual framboids. Note that this nano-structure is only visible in the $\mathrm{C}$ and $\mathrm{CN}$ images. 

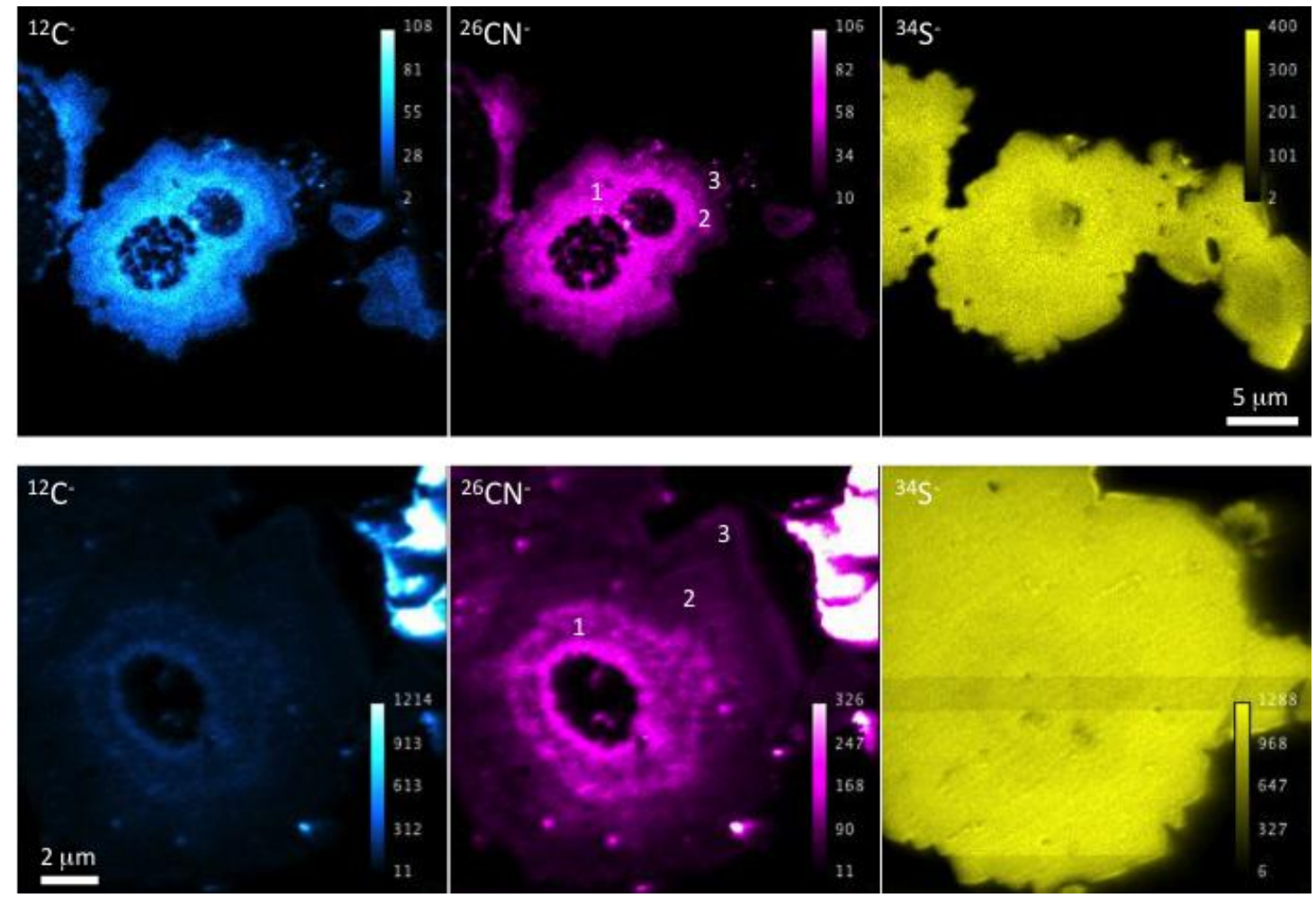

Figure DR5. Examples of concentric zoning of organic material in pyrite framboid overgrowths. Pyrite closest to the original framboids shows the highest concentration of organic material (1). Two further zones (2 and 3) record decreasing concentrations of organic material as the pyrite overgrowth increases in size. Note that sulfur signal is rather uniform across all zones. 


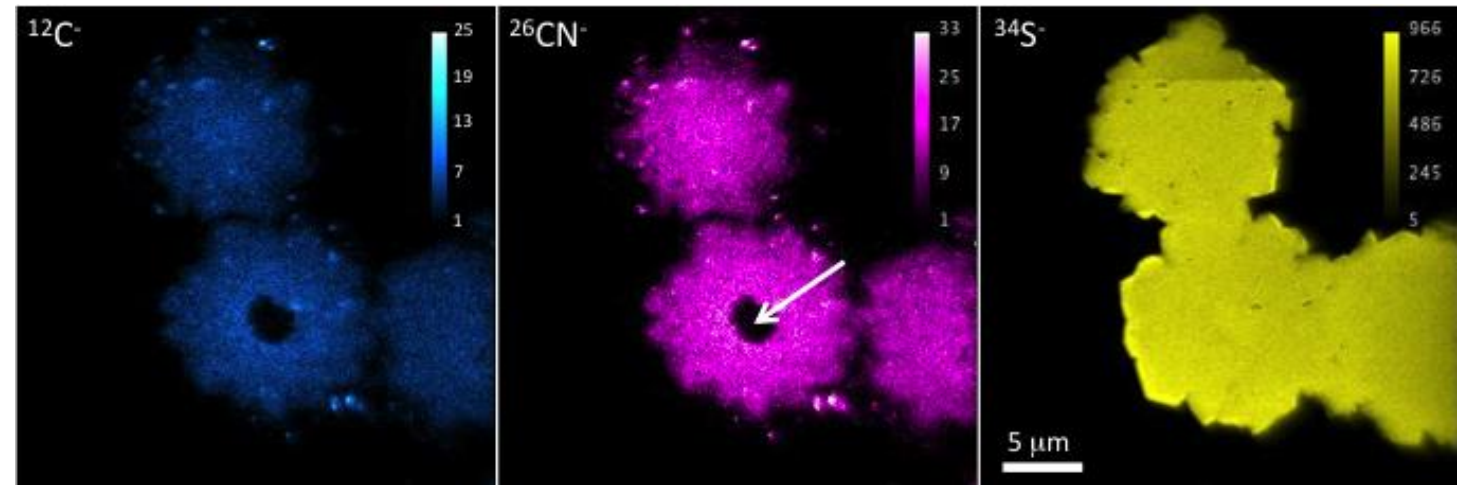

Figure DR6. NanoSIMS ion maps of carbon $\left({ }^{12} \mathrm{C}^{-}\right)$, nitrogen $\left({ }^{26} \mathrm{CN}^{-}\right)$and sulfur $\left({ }^{34} \mathrm{~S}^{-}\right)$ showing more poorly preserved pyrite framboids. The internal zone of micro-grains in an organic matrix is not preserved, being replaced by either a spheroidal pure pyrite core (arrow) or in other cases homogenous organic-rich pyrite. 
Table DR1. Sulfur isotope data $\left(\delta^{34} \mathrm{~S}_{\mathrm{V}-\mathrm{CDT}} \%\right)$ from framboidal pyrite within the c.

560 Ma Fermeuse formation of Newfoundland (sample WM1).

$\begin{array}{cccc}\text { Analysis ID } & { }^{34} \text { S counts } & \delta^{34} S_{\mathrm{V}-\mathrm{CDT}} & \pm 2 \sigma(\%) \\ & & & \\ & & & \\ \text { SESSION 1 (NANOSIMS) } & \\ \text { SON-3_1 } & \left(\mathbf{x 1 0 ^ { 6 } )}\right. & & \\ \text { SON-3_2 } & 5.42 & 1.8 & 1.1 \\ \text { SON-3_3 } & 5.24 & 1.4 & 0.9 \\ \text { SON-3_4 } & 5.24 & 2.4 & 0.9 \\ \text { SON-3_5 } & 5.23 & 0.6 & 0.9 \\ \text { SON-3_6 } & 5.18 & 2.3 & 1.0 \\ \text { SON-3_7 } & 5.20 & 3.0 & 1.0 \\ \text { SON-3_8 } & 5.19 & -0.4 & 1.0 \\ \text { SON-3_9 } & 5.18 & 1.8 & 1.1 \\ \text { SON-3_10 } & 5.23 & 1.2 & 1.4 \\ \text { SON-3_11 } & 5.12 & 1.1 & 1.5 \\ & 5.09 & 2.6 & 1.5 \\ & & \text { Mean }=1.6 & \end{array}$

\section{Sample WM1}

WM 1a

WM_1b

WM_1c

WM_2a

WM $2 b$

WM_3a

WM_3b

WM_5a

WM $5 b$

WM_6a

WM_6b

WM_7a

WM_7b

WM_7c

WM_7d

WM_1d

$$
\begin{aligned}
& 4.75 \\
& 5.31 \\
& 5.13 \\
& 4.95 \\
& 4.95 \\
& 5.00 \\
& 4.82 \\
& 4.21 \\
& 4.71 \\
& 4.96 \\
& 4.97 \\
& 5.46 \\
& 5.13 \\
& 5.01 \\
& 5.13 \\
& 5.12
\end{aligned}
$$

$-21.8$

$-23.5$

$-20.4$

$-23.6$

$-21.2$

$-22.1$

$-21.4$

$-18.7$

$-19.5$

$-19.4$

$-22.6$

$-21.1$

$-24.2$

$-23.1$

$-19.6$

$-24.3$

0.9

0.8

0.8

0.9

0.9

0.9

0.9

1.0

1.0

1.1

1.1

1.2

1.2

1.3

1.3

1.4

\section{SESSION 2 (IMS 1280)}

Standards
SON-3_1
SON-3_2
SON-3_3
SON-3_4
SON-3_5
SON-3_6
SON-3_7
SON-3_8
SON-3_9
SON-3_10
SON-3_11
SON-3_12

$\left(\times 10^{10}\right)$

$\begin{array}{lll}1.99 & 1.57 & 0.06 \\ 1.98 & 1.57 & 0.06 \\ 1.99 & 1.66 & 0.06 \\ 1.99 & 1.58 & 0.06 \\ 2.02 & 1.60 & 0.06 \\ 2.07 & 1.67 & 0.05 \\ 2.07 & 1.60 & 0.05 \\ 2.09 & 1.66 & 0.05 \\ 2.07 & 1.61 & 0.05 \\ 2.11 & 1.63 & 0.05 \\ 2.11 & 1.65 & 0.06 \\ 2.11 & 1.66 & 0.06\end{array}$




$\begin{array}{ll}\text { SON-3_13 } & 2.11 \\ \text { SON-3_14 } & 2.11 \\ \text { SON-3_15 } & 2.13 \\ & \\ & \\ \text { FREO_1 } & 1.96 \\ \text { FREO_2 } & 2.05 \\ \text { FREO_3 } & 2.07\end{array}$

$\begin{array}{cc}1.56 & 0.06 \\ 1.55 & 0.06 \\ 1.58 & 0.06 \\ \text { Mean }=1.61 & \\ \text { SD }=0.04 & \\ -4.49 & 0.05 \\ -4.40 & 0.05 \\ -4.44 & 0.06 \\ \text { Mean }=-4.45 & \\ \text { SD }=0.05 & \\ \end{array}$

$\begin{array}{cccc}\text { Sample WM1 } & & & \\ \text { WM_1 } & 1.47 & -23.48 & 0.08 \\ \text { WM_2 } & 0.81 & -23.15 & 0.08 \\ \text { WM_3 } & 0.86 & -24.23 & 0.10 \\ \text { WM_4 } & 1.12 & -15.21 & 0.07 \\ \text { WM_5 } & 0.58 & -20.90 & 0.07 \\ \text { WM_6 } & 0.92 & -22.12 & 0.06 \\ \text { WM_7 } & 0.92 & -21.42 & 0.15 \\ \text { WM_8 } & 1.35 & -21.29 & 0.08 \\ \text { WM_9 } & 1.12 & -21.33 & 0.11 \\ \text { WM_10 } & 1.06 & -21.26 & 0.10 \\ \text { WM_11 } & 0.40 & -20.71 & 0.16 \\ \text { WM_12 } & 0.65 & -21.13 & 0.12 \\ \text { WM_13 } & 1.33 & -20.60 & 0.08 \\ \text { WM_14 } & 1.15 & -22.00 & 0.06 \\ \text { WM_15 } & 0.65 & -18.85 & 0.12 \\ \text { WM_16 } & 0.40 & -22.76 & 0.09 \\ \text { WM_17 } & 0.50 & -23.75 & 0.17\end{array}$

\section{Methods}

Focussed ion beam (FIB) preparation of TEM samples

A dual-beam FIB system (FEI Nova NanoLab) at the Electron Microscopy Unit, University of New South Wales was used to prepare pyrite framboid TEM samples from standard uncovered polished geological thin sections coated with c. $30 \mathrm{~nm}$ of gold. Electron beam imaging was used to identify framboids of interest in the polished thin sections allowing site-specific TEM samples to be prepared. The TEM sections were prepared by a series of steps involving different beam energies and currents (see Wacey et al., 2012), resulting in ultrathin wafers of c. $100 \mathrm{~nm}$ thickness. These TEM wafers were extracted using an ex-situ micromanipulator and deposited on continuous-carbon copper TEM grids. FIB preparation of TEM sections allows 
features below the surface of the thin sections to be targeted, thus eliminating the risk of surface contamination producing artefacts.

\section{TEM analysis of FIB-milled wafers}

TEM data were obtained using a FEI Titan G2 80-200 TEM/STEM with ChemiSTEM Technology operating at $200 \mathrm{kV}$, plus a JEOL $2100 \mathrm{LaB}_{6}$ TEM operating at $200 \mathrm{kV}$ equipped with a Gatan Orius CCD camera and Tridiem energy filter. Both instruments are located in the Centre for Microscopy, Characterisation and Analysis (CMCA) at The University of Western Australia. HAADF (high angle annular darkfield) STEM images and EDS (ChemiSTEM) maps were obtained on the FEI Titan. Energy filtered (EFTEM) elemental maps were obtained on the JEOL 2100 using the conventional three-window technique (Brydson, 2001), with energy windows selected to provide optimum signal-to-noise.

\section{NanoSIMS ion mapping}

Ion mapping was performed using a CAMECA NanoSIMS 50 at CMCA, The University of Western Australia, with instrument parameters optimized as described in Wacey et al. (2011). Analysis areas varied from $12 \times 12 \mu \mathrm{m}$ up to $30 \times 30 \mu \mathrm{m}$, at a resolution of $256 \times 256$ pixels (each pixel measuring between $47 \mathrm{~nm}$ and $117 \mathrm{~nm}$, depending on the image area), with a dwell time of $20 \mathrm{~ms}$ per pixel, and a primary beam current of c. 2.5 pA. Secondary ions mapped were ${ }^{12} \mathrm{C}^{-},{ }^{26} \mathrm{CN}^{-}$, and ${ }^{34} \mathrm{~S}^{-}$(note the use of ${ }^{34} \mathrm{~S}^{-}$instead of ${ }^{32} \mathrm{~S}^{-}$, because ${ }^{32} \mathrm{~S}^{-}$provided too many counts to the electron multiplier detector at the conditions required for good ${ }^{12} \mathrm{C}^{-}$and ${ }^{26} \mathrm{CN}^{-}$imaging), and charge compensation was achieved by using the electron flood gun. 
NanoSIMS sulfur isotope analysis

Sulfur isotope ratios $\left({ }^{34} \mathrm{~S} /{ }^{32} \mathrm{~S}\right)$ from individual pyrite grains were determined using a CAMECA NanoSIMS 50 at CMCA, The University of Western Australia. The analyses were performed using a Faraday Cup (FC) detector for the ${ }^{32} \mathrm{~S}$ signal and an electron multiplier (EM) for the ${ }^{34} \mathrm{~S}$ signal, with a primary beam current of c. $2.5 \mathrm{pA}$, and a raster area of $3 \times 3 \mu \mathrm{m}$. Instrument setup, data acquisition, drift correction, instrumental mass fractionation correction and error propagation were carried out according to the protocol described in McLoughlin et al. (2012). All samples were confirmed as pyrite using laser Raman spectroscopy, so no corrections for matrix effects between the samples and our SON-3 pyrite standard were applied. Analyses were completed over a single analytical session with an uncertainty on bracketing $\delta^{34} \mathrm{~S}$ standard analyses of $1.0 \%(1 \mathrm{SD} ; \mathrm{n}=11)$. Propagated errors for individual analyses $(2 \sigma)$ are listed in the final column of Table DR1.

\section{IMS 1280 sulfur isotope analysis}

\section{Instrument setup}

Sulfur isotope ratios $\left({ }^{34} \mathrm{~S} /{ }^{32} \mathrm{~S}\right)$ were determined using a CAMECA IMS 1280 ion microprobe operating in multi-collection mode at CMCA, The University of Western Australia. In all cases NMR regulation was used and ${ }^{32} \mathrm{~S}$ and ${ }^{34} \mathrm{~S}$ were measured using Faraday cup detectors (FC). A rastered beam approach employing dynamic transfer was used. A $3.5 \mathrm{nA}$ focused primary beam was used to pre-sputter the analysis area using a $30 \mu \mathrm{m} \times 30 \mu \mathrm{m}$ beam for 40 seconds followed by automated secondary centering in the field aperture (FA) and entrance slit (ES); and analysis using a $20 \mu \mathrm{m} \times 20 \mu \mathrm{m}$ raster employing dynamic transfer for $45 \times 4$ second integrations. Unknowns were bracketed with standards of known composition. Other 
conditions include a $133 \times$ magnification between sample stage and field aperture (FA), $70 \mu \mathrm{m}$ entrance slit, $4000 \mu \mathrm{m}$ FA, $400 \mu \mathrm{m}$ contrast aperture, a $40 \mathrm{eV}$ energy window with a $5 \mathrm{eV}$ offset to the high energy side, and $500 \mu \mathrm{m}$ exit slits. Although the pyrite targets are conductors, the normal incidence electron flood gun was utilized for charge compensation in the event that the primary ion beam overlapped onto insulating matrix silica minerals. External precision of ${ }^{34} \mathrm{~S} /{ }^{32} \mathrm{~S}$ on the SON-3 standard for the analytical session was better than $0.05 \%$ ( $1 \mathrm{SD} ; \mathrm{n}=15)$. A secondary standard (FREO) was run as an unknown in some cases. These samples returned a mean value of $-4.45 \pm 0.05 \%$ ( $1 \mathrm{SD}, \mathrm{n}=3)$, which is in good agreement with the laser fluorination value of $-4.3 \%$. Sample count rates varied between $\sim 20 \%$ and 75 $\%$ of the count rate of the standard, however, there was no observed correlation between secondary count rate and $\delta^{34} \mathrm{~S}$ of the samples.

\section{Data processing}

Instrumental mass fractionation and propagation of uncertainty follow the protocol in Farquhar et al. (2013). Uncertainty terms included internal uncertainty, external uncertainty of the instrumental mass fractionation of the primary standard, and uncertainty of the standard relative to V-CDT.

\section{References for repository items}

Brydson, R., 2001, Electron Energy Loss Spectroscopy: Springer-Verlag, New York. Farquhar, J., Cliff, J., Zerkle, A.L., Kamyshny, A., Poulton, S.W., Claire, M., Adams, D., and Harms, B., 2013, Pathways for Neoarchean pyrite formation constrained by mass-independent sulfur isotopes: Proceedings of the National Academy of Sciences USA, v. 110, p. 17638-17643. 
McLoughlin, N., Grosch, E.G., Kilburn, M.R, and Wacey, D., 2012, Sulfur isotope evidence for a Paleoarchean subseafloor biosphere, Barberton, South Africa: Geology, v. 40, p. 1031-1034.

Sim, M.S., Bosak, T., and Ono, S., 2011, Large sulfur isotope fractionation does not require disproportionation: Science, v. 333, p. 74-77.

Wacey D., Kilburn, M.R., Saunders, M., Cliff, J., and Brasier, M.D., 2011, Microfossils of sulphur-metabolizing cells in 3.4 billion-year-old rocks of Western Australia: Nature Geoscience, v. 4, p. 698-702.

Wacey, D., Menon, S., Green, L., Gerstmann, D., Kong, C., McLoughlin, N., Saunders, M., and Brasier, M.D., 2012, Taphonomy of very ancient microfossils from the $\sim 3400$ Ma Strelley Pool Formation and 1900 Ma Gunflint Formation: new insights using focused ion beam: Precambrian Research, v. 220-221, p. 234 250. 